\title{
Validation of the Hungarian version of the short form of Spiritual Connection Questionnaire (SCQ-14)
}

\author{
BARBARA CSALA ${ }^{1,2 *}$ - FERENC KÖTELES ${ }^{2}$ \\ ${ }^{1}$ Doctoral School of Psychology, ELTE Eötvös Loránd University, Budapest, Hungary \\ ${ }^{2}$ Institute of Health Promotion and Sport Sciences, ELTE Eötvös Loránd University, \\ Budapest, Hungary
}

(Received: 27 November 2020, accepted: 7 March 2021)

Background: Spirituality is a human specific phenomenon associated with positive mental and physical health outcomes. From a scientific point of view, it is a complex construct which can be investigated in various ways. The Spiritual Connection Questionnaire (SCQ) measures spirituality independently from religiousness thus it appears to be an appropriate measure to assess religious and non-religious aspects of spirituality. Aim: The present study aimed to develop and validate the Hungarian version of the short form of the Spiritual Connection Questionnaire (SCQ-14). Furthermore, it aimed to investigate spirituality's association with affect and thinking style. Methods: Participants of two nonrepresentative community samples $(n=387$ and $n=145)$ completed the following questionnaires online: short form of the Spiritual Connection Questionnaire, Spiritual Transcendence Scale, Rational-Experiential Inventory, and Positive and Negative Affect Schedule. Results: The Hungarian SCQ-14 showed an excellent internal consistency (Cronbach's $\alpha=0.94$ and 0.97 on Sample 1 and 2, respectively). Confirmatory factor analyses indicated inappropriate fit with the theoretically assumed one-factor model $\left(\chi^{2}=\right.$ 435.848, $\mathrm{df}=77, p<0.001 ; \mathrm{CFI}=0.904 ; \mathrm{NFI}=0.886$; $\mathrm{RMSEA}=0.110[90 \% \mathrm{CI}=0.100-0.120]$ on Sample 1, and $\chi^{2}=247.132, \mathrm{df}=77, p<0.001 ; \mathrm{CFI}=0.917 ; \mathrm{NFI}=0.885 ;$ RMSEA $=0.123$ [90\% CI $=0.106-0.141]$ on Sample 2). In contrast, results of exploratory factor analyses indicated a one-factor structure on both samples. The SCQ-14 was positively associated with spiritual transcendence, experiential thinking style, and partly with positive affect. No significant correlations with rational thinking style and negative affect were found. Results of the multiple hierarchical linear regression analysis on both samples revealed a significant contribution of experiential thinking style and spiritual transcendence to spiritual connection after controlling for gender, age, educational qualification, and positive affect. Conclusions: The Hungarian version of the Spiritual Connection Questionnaire (SCQ-14) is a valid, psychometrically sound measure. Spiritual transcendence and experiential thinking style independently contribute to spiritual connection.

Keywords: spirituality, SCQ-14, experiential thinking style, affect

\footnotetext{
* Correspondence: Barbara Csala, Institute of Health Promotion and Sport Sciences, ELTE Eötvös Loránd University, H-1119 Budapest, Bogdánfy u 10./B. E-mail: csala.barbara@ppk.elte.hu
} 
"If we omit spiritual realities from our account of human behavior,
it won't matter much what we keep in, because we will have omitted the most
fundamental aspect of human behavior"(Bergin, 1997, p. xi)

\section{Introduction}

Spirituality is a complex construct which can be approached from various viewpoints, e.g., from psychological, philosophical, transcendentalreligious, and phenomenological directions. The term originates in the Latin word "spiritus" which means breath, a vital principle of a human being (Simpson \& Weiner, 1989). Spirituality has been defined as a universal, solely human phenomenon (Emmons, 2006; Piedmont \& Leach, 2002; Tomcsányi et al., 2011), as a search for and a belief in something sacred beyond the material world (Emmons, 2006; Hill \& Pargament, 2003). Thus, spirituality can be described as a motivational process to discover the transcendent, the divine, the ultimate truth and connect to this larger sacredness (Emmons, 2006; Hill \& Pargament, 2003; Piedmont, 1999). Spirituality is furthermore a subjective experience based on deep understanding of the world, the perceived sense of truth (Heelas \& Woodhead, 2005), a feeling of connectedness, wholeness and openness to the infinite (Kelly, 1995). It refers to a conscious detection of the transcendent dimension and involves defined values respecting all aspects of life (Elkins et al., 1988). Spirituality can also be captured as an ability to sense the sacredness of everyday experiences, responsibilities, roles and goals (Piedmont, 1999). Finally, according to Wheeler and Hyland (2008), it reflects the feeling of connection with the universe, with others, with nature and places, and also the sense of happiness which comes from this connectedness.

Although spirituality was originally not discriminated from religiousness, the two concepts are not identical (Emmons, 2006; Tomcsányi et al., 2011). Religion (particularly in the Western culture) is a fellowship based on commonly accepted, unquestionable faith which provides the knowledge of a transcendent reference point, namely God, and shows the path to reach it (Hill \& Pargament, 2003; Pikó et al., 2011). It represents a system of beliefs, religious practices and symbols which is given as the solely path to the ultimate world (Emmons, 2006; Hill \& Pargament, 2003). In contrast, the term spirituality refers to a free, individual search for the sacred which obviously does not exclude religious attempts. It is a spontaneous, informal, subjective experience and expression (Koenig et al., 2001). Despite of these differences, religiousness and spirituality show a considerable overlap. Their shared aspects are the search for the sacred, and the connection to others and the transcendent which gives an integrative strength for the 
person. Thus, both can function as a coping resource (Hill \& Pargament, 2003; Tomcsányi et al., 2011). Nevertheless, spirituality can appear in both religious and not religious form (namely, traditional or nontraditional form) and is considered a broader concept than religiousness (Oman, 2013; Pikó et al., 2011; Zinnbauer et al., 1997). It is often regarded as the highest human potential (Emmons, 2006), an innate, universal, human specific phenomenon (Piedmont, 2005).

Within the concept of spirituality, dualist and non-dualist views exist (Wheeler \& Hyland, 2008). According to the dualist approach, the material and the spiritual world represent two different realms, i.e., an independent spiritual reality beyond material life is assumed. This belief concurs most of religious traditions, thus in this interpretation spirituality and religiousness are highly overlapping (Pargament, 1999; Wheeler \& Hyland, 2008). In contrast, the non-dualist view holds that there is only one reality with seemingly different aspects. According to this approach, everything is interconnected and governed by the same laws or principles.

\subsection{Scientific approaches and assessment of spirituality}

The complexity of the construct and the heterogeneity of approaches make the scientific inquiry on spirituality particularly difficult (Oman, 2013). According to Emmons (2006), scientific studies on spirituality encompass three levels of analysis: (1) spirituality as a trait (e.g., spiritual transcendence; (Piedmont, 1999)); (2) spirituality as personal goals; and (3) spirituality in emotions, like gratitude, awe, wonder, or forgiveness (Emmons, 2006). From the viewpoint of positive psychology, spirituality (as a form of transcendence) is a character strength (Pikó et al., 2011; Shryack et al., 2010). Maslow (1969) and Frankl (1966) denote that self-transcendence and spirituality are integral parts of a human being providing meaning of life and perceived freedom, thus they can serve as coping tools in extreme life situations, crises, and chronic diseases (Garcia-Romeu, 2010; Kopp et al., 2004; Pikó et al., 2011).

In the last decades, a number of self-report tools were developed to assess various aspects of the construct, such as Spiritual Support Scale (Maton, 1989), Index of Core Spiritual Experiences (Kass et al., 1991), Spiritual Transcendence Scale (STS) (Piedmont, 2004), Spiritual Assessment Inventory (Hall \& Edwards, 1996), or Spiritual History Scale (Hays et al., 2001). As the majority of these questionnaires apply a religious and/or dualistic approach to spirituality, Wheeler and Hyland (2008) intended to develop a measurement tool that assesses spirituality independently from religiousness, and that is able to assess both dualistic and non-dualistic perspectives of spirituality. They focused on one key component of spiritual 
experience, namely spiritual connection, that captures spirituality well among both religious and non-religious individuals (Wheeler \& Hyland, 2008). The 48-item questionnaire (Spiritual Connection Questionnaire; SCQ-48) measures five facets of the construct: (1) connection with universe, (2) others, (3) nature and (4) places, and (5) the sense of associated joy and happiness. A shorter version with 14 items (SCQ-14) was also developed, based on three facets (1,2, and 5). Empirical findings indicated that the 14item Spiritual Connection Questionnaire is a valid unidimensional measure of spirituality (Wheeler \& Hyland, 2008).

\subsection{Associations with other constructs}

In the past decades, evidence concerning positive mental and physical health outcomes of spirituality has accumulated (Fetzer/NIA Working Group, 1999). Positive associations with subjective well-being, satisfaction with life, quality of life, personal growth, vitality, self-esteem, and resilience were reported (Emmons, 2006; Fetzer/NIA Working Group, 1999; Klein et al., 2016; Piedmont, 2007; Wheeler \& Hyland, 2008). Moreover, it was found to be associated with lower levels of psychological distress, depressive symptoms, and suicide attempts (Fetzer/NIA Working Group, 1999; Piedmont, 2007). Spirituality also contributes to positive affect (Geary, 2003; Komninos, 2009; Powers et al., 2007), a widely used indicator of subjective well-being. Thus, spirituality can be noted as an effective strategy to increase well-being (Henry, 2006).

Spirituality, although it is considered an exclusively human phenomenon, presumably has an evolutionary background (Emmons, 2006; Piedmont, 2005). A number of authors proposed that there are two basic and different ways of human information processing: one is an intuitive, automatic process which is age and intelligence independent and has a long evolutionary history (i.e., also present in the animal kingdom), while the other is a logical, analytic, effortful mechanism with a comparatively short evolutionary history (Chaiken, 1980; Epstein et al., 1996; Pacini \& Epstein, 1999; Tversky \& Kahneman, 1983). A comprehensive theory, called cognitive-experiential self-theory (CEST) or later cognitive-experiential theory (CET), was developed by Seymour Epstein (Epstein, 1994, 2014; Epstein et al., 1996). It describes two independent thinking styles: rational and experiential. Rational thinking is a human specific process primarily based on language. It requires considerable mental effort to conduct a conscious reasoning based on all available information. It is relatively slow, but mostly results in answers and solutions which fit to reality the most. In 
contrast, experiential thinking style is a more ancient, non-verbal process, an unconscious, automatic, and effortless mechanism. It is based on subjective experiences and feelings, it works very fast, though the outcome can be mistaken (Epstein, 1994, 2014). CET declares that the two processes are independent and function by different rules. Moreover, individuals show considerable differences in the extent they rely on the two thinking styles (Epstein et al., 1996).

Rational and experiential thinking styles have different concomitants. The former is associated with constructive, action-oriented coping, while the latter is associated with emotionally positive, naive, unrealistic thinking and favourable beliefs (Epstein et al., 1996; Pacini \& Epstein, 1999). In empirical studies, experiential thinking was related to preference of complementary and alternative medicine (Saher \& Lindeman, 2005), modern health worries (Köteles et al., 2016) as well as paranormal and magical beliefs (Lindeman \& Aarnio, 2007). Experiential thinking is assumed to be holistic and revealed to have a moderate connection with spirituality (Köteles et al., 2016). This supports the idea that spirituality might show a considerable overlap with experiential thinking style.

\subsection{Aim of the present study}

The present study aims to develop and validate the Hungarian version of the short version of Spiritual Connection Questionnaire (SCQ-14). We supposed that spiritual connection shows (1) a positive association with experiential thinking style and (2) spiritual transcendence (STS) (convergent validity). Furthermore, we hypothesized that spiritual connection shows a positive correlation with (3) positive affect, and (4) negative correlation with negative affect. Finally (5), no correlation with the rational thinking style was expected.

\section{Materials and methods}

\subsection{Participants and procedure}

Adult participants were recruited and questionnaires were completed online in Hungarian. The research was conducted by the approval of the Research Ethics Committee of the Faculty of Education and Psychology, Eötvös Loránd University, Hungary (Ethical approval number: 2014/09 and 2018/269). All participants signed an online informed consent form before the completion of the questionnaires. 
Sample 1: A non-representative community sample (Sample 1: $n=387$; age: $\mathrm{M}=28.75$ years, $\mathrm{SD}=12.22$ years; $29.2 \%$ male; educational qualification: $2.3 \%$ was characterized by elementary school, $61.3 \%$ by high school, and $36.4 \%$ by university degree) was collected via 31 thematic Facebook groups belonging to cities, villages and local sport associations which were not associated with any aspect of spirituality, religiousness, rational thinking, or scientific content. Data collection took place in spring 2015.

Sample 2: To replicate results, a second community sample (Sample 2: $n=$ 145; age: $\mathrm{M}=37.43$ years, $\mathrm{SD}=13.79$ years; $23.4 \%$ male; educational qualification: $0.7 \%$ was characterized by elementary school, $22.1 \%$ by high school, and $77.2 \%$ by university degree) was recruited similarly through Facebook groups in autumn 2018. Facebook groups were mostly belonging to cities (but not to villages) and communities of pensioners, however, no local sport associations groups were involved. (This sampling difference might be the explanation of the uneven mean age data of the two samples.)

\subsection{Questionnaires}

The short version of the Spiritual Connection Questionnaire (SCQ-14) (Wheeler \& Hyland, 2008) aims to assess spiritual connection as a subjective experience which is independent from religious contents, thus applicable on both religious and non-religious samples. The 14 items measure on a seven-point Likert scale from 1 ("definitely not agree") to 7 ("definitely agree"), higher scores represent higher level of spiritual connection. The scale is freely accessible and usable. Development of the Hungarian version followed the usual translation-backtranslation procedure. The scale was translated into Hungarian by two independent experts, then a third expert translated back the consensus version. The back-translated version was compared to the original by Michael Hyland, the author of the original scale (see the Appendix for the final version). Cronbach's $\alpha$ coefficients were 0.94 and 0.97 on Sample 1 and Sample 2, respectively.

The Spiritual Transcendence Scale (STS) (Piedmont, 2004; Tomcsányi et al., 2011) measures the ability of a person to stand outside of the present, actual time and place and to have a larger view of life, a more objective perspective. The short form comprises 9 items rated on a 5-point Likert scale ranging from 1 ("strongly disagree") to 5 ("strongly agree"). Higher scores predict higher level of spiritual transcendence, i.e., the individual views life more as a part of a larger plan and is more prone to believe that there is something beyond mortal existence. The use of the scale was approved by the author (R. L. Piedmont). Cronbach's $\alpha$ values were 0.79 (Sample 1) and 0.81 (Sample 2). 
For the assessment of thinking styles, the revised version of the RationalExperiential Inventory (REI) (Bognár et al., 2014; Pacini \& Epstein, 1999) was used. The questionnaire consists of two 20-item scales measuring the two independent thinking styles: rational and intuitive-experiential. Items are rated on a five-point Likert scale from 1 ("definitely not true of myself") to 5 ("definitely true of myself"), higher scores refer to higher levels of rational and intuitive-experiential thinking, respectively. Cronbach's $\alpha$ coefficients were 0.87 and 0.89 (rational and intuitive-experiential thinking style, respectively) on Sample 1 and 0.88 and 0.91 on Sample 2.

Positive and Negative Affect Schedule (PANAS) (Gyollai et al., 2011; Watson et al., 1988) comprises two independent scales with 10-10 items. The positive affect scale describes the extent to which the individual feels active, alert and enthusiastic. The negative affect scale measures subjective distress and unpleasant mood states like guilt or fear. Evaluation of the items are on a 5-point Likert scale from 1 ("very slightly or not at all") to 5 ("extremely"), higher scores show higher positive or negative affect. Cronbach's $\alpha$ coefficients of both positive and negative affect were uniformly 0.86 on Sample 1 and 0.83 on Sample 2.

\subsection{Statistical analysis}

Data analysis was conducted using the SPSS v25 software (IBM Corp, 2017). Confirmatory factor analysis (CFA) was conducted using the JASP v0.14.2 software (JASP Team, 2020). Data of both samples were appropriate for factor analysis (Sample 1: KMO = 0.952; Bartlett-test $=3751.1, \mathrm{p}<0.001$; Sample 2: $\mathrm{KMO}=0.955$; Bartlett-test $=2048.333$, $\mathrm{p}<0.001)$. Model fit was evaluated with the Comparative Fit Index (CFI), the Normed Fit Index (NFI), and the Root Mean Square Error of Approximation (RMSEA) based on common standards: acceptable/good fit: CFI, NFI $\geq 0.90 / 0.95$; RMSEA $\leq 0.08 / 0.06$ (Browne \& Cudeck, 1993; Hu \& Bentler, 1999). Following the original study from Wheeler and Hyland (2008), factor structure of the scale was also checked with exploratory factor analysis (EFA), using the maximum likelihood method.

For both samples, associations with the validating questionnaires were estimated using Spearman correlation due to violation of normality for the majority of variables. Finally, hierarchical linear regression analyses were conducted with spiritual connection as criterion variable. Variables were entered in the equation in three steps: (1) socio-demographic control variables (age; gender [male $=0$, female $=1]$; educational qualification 1 [elementary school (0) or higher (1)], educational qualification 2 [high school (0) or higher (1)]), (2) positive affect and (3) experiential thinking style and STS (spiritual transcendence) score. 


\section{Results}

\subsection{Sample 1}

\subsubsection{Psychometric properties}

Descriptive statistics of the items are presented in Table 1. The Hungarian version of the SCQ-14 is characterized by excellent internal consistency (Cronbach's $\alpha=0.94$ ), which does not show substantial changes after the removal of any of the items (Table 1). CFA indicated inappropriate fit with the theoretically assumed one-factor model $\left(\chi^{2}=435.848, \mathrm{df}=77, p<0.001\right.$; $\mathrm{CFI}=0.904 ; \mathrm{NFI}=0.886$; RMSEA $=0.110[90 \% \mathrm{CI}=0.100-0.120]$ ), which could not be further improved by assuming associations between variables based on high modification indices. In contrast, EFA indicates a one-factor structure: the only factor with an eigenvalue higher than 1 (8.188) explains $58.45 \%$ of the total variance. Moreover, loadings of all items on factor 1 are higher than 0.6 (Table 1).

Table 1. Descriptive statistics of the items, their contributions to the internal consistency of the scale, and loadings on Factor 1 yielded by factor analysis in Sample 1

\begin{tabular}{|l|c|c|c|c|}
\hline \multicolumn{1}{|c|}{ Items } & M \pm SD & $\begin{array}{c}\text { Corrected item- } \\
\text { total correlation }\end{array}$ & $\begin{array}{c}\text { Cronbach's } \alpha \\
\text { if item deleted }\end{array}$ & $\begin{array}{c}\text { Loading } \\
\text { on Factor 1 }\end{array}$ \\
\hline $\begin{array}{l}\text { 1. My spirituality } \\
\text { makes life good for me. }\end{array}$ & $4.10 \pm 1.917$ & 0.777 & 0.938 & 0.823 \\
\hline $\begin{array}{l}\text { 2.* I feel no spiritual } \\
\text { connection to the } \\
\text { world around me. }\end{array}$ & $4.33 \pm 2.016$ & 0.694 & 0.940 & 0.712 \\
\hline $\begin{array}{l}\text { 3. I sometimes } \\
\text { experience other } \\
\text { people 'shining with } \\
\text { an inner light'. }\end{array}$ & $3.35 \pm 1.967$ & 0.631 & 0.942 & 0.658 \\
\hline $\begin{array}{l}\text { 4. }{ }^{*} \text { I have never had a } \\
\text { spiritual experience } \\
\text { that has changed my } \\
\text { life. }\end{array}$ & $3.98 \pm 2.327$ & 0.601 & 0.943 & 0.612 \\
\hline $\begin{array}{l}\text { 5. There is a larger plan } \\
\text { to life. }\end{array}$ & $4.12 \pm 2.063$ & 0.572 & 0.943 & 0.579 \\
\hline $\begin{array}{l}\text { 6. }{ }^{*} \text { I do not feel that } \\
\text { there is a form of } \\
\text { energy that binds } \\
\text { people together. }\end{array}$ & $4.47 \pm 2.075$ & 0.700 & 0.940 & 0.702 \\
\hline
\end{tabular}


Table 1. (Continued)

\begin{tabular}{|l|c|c|c|c|}
\hline \multicolumn{1}{|c|}{ Items } & M \pm SD & $\begin{array}{c}\text { Corrected item- } \\
\text { total correlation }\end{array}$ & $\begin{array}{c}\text { Cronbach's } \alpha \\
\text { if item deleted }\end{array}$ & $\begin{array}{c}\text { Loading } \\
\text { on Factor 1 }\end{array}$ \\
\hline $\begin{array}{l}\text { 7. I feel I have an inner } \\
\text { spiritual strength. }\end{array}$ & $3.80 \pm 2.030$ & 0.763 & 0.938 & 0.795 \\
\hline $\begin{array}{l}\text { 8.* I do not have a } \\
\text { personal relationship } \\
\text { with some power } \\
\text { greater than myself. }\end{array}$ & $3.80 \pm 2.326$ & 0.703 & 0.940 & 0.709 \\
\hline $\begin{array}{l}\text { 9. I feel an inner } \\
\text { strength from a } \\
\text { spiritual connection } \\
\text { with others. }\end{array}$ & $3.28 \pm 1.955$ & 0.752 & 0.939 & 0.773 \\
\hline $\begin{array}{l}\text { 10.* Spirituality is not } \\
\text { important to me. }\end{array}$ & $4.15 \pm 2.241$ & 0.795 & 0.937 & 0.824 \\
\hline $\begin{array}{l}\text { 11. I feel that I am } \\
\text { always protected by an } \\
\text { ultimate principle, } \\
\text { force or being. }\end{array}$ & $3.94 \pm 2.194$ & 0.712 & 0.940 & 0.729 \\
\hline $\begin{array}{l}\text { 12.* I will never have a } \\
\text { spiritual bond with } \\
\text { another person. }\end{array}$ & $4.70 \pm 1.973$ & 0.786 & 0.938 & 0.811 \\
\hline $\begin{array}{l}\text { 13. My connection to } \\
\text { something spiritual } \\
\text { makes me happy. }\end{array}$ & $3.84 \pm 1.956$ & 0.802 & 0.937 & 0.846 \\
\hline $\begin{array}{l}\text { 14.* I do not feel } \\
\text { connected to the } \\
\text { universe in any } \\
\text { spiritual way. }\end{array}$ & $4.13 \pm 2.186$ & 0.767 & & \\
\hline
\end{tabular}

Note. $n=387, *$ : reversed item.

\subsubsection{Convergent validity and associations}

Descriptive statistics of the assessed psychological variables and results of the correlation analysis are presented in Table 2. The SCQ-14 score shows a strong correlation with STS $\left(r_{\mathrm{s}}=0.69, p<0.001\right)$, a medium level connection with the experiential thinking style $\left(r_{\mathrm{s}}=0.45, p<0.001\right)$, and a weak to moderate association with positive affect $\left(r_{\mathrm{s}}=0.28, p<0.001\right)$. Associations with the rational thinking style and negative affect were non-significant and close to zero. 
Table 2. Descriptive statistics $(\mathrm{M} \pm \mathrm{SD})$ of the assessed variables, and results of correlation analysis (Spearman's rho coefficients) in Sample 1

\begin{tabular}{|c|c|c|c|c|c|c|}
\hline Variables & SCQ-14 & STS & $\begin{array}{l}\text { Rational } \\
\text { thinking } \\
\text { style (REI) }\end{array}$ & $\begin{array}{l}\text { Experiential } \\
\text { thinking } \\
\text { style (REI) }\end{array}$ & $\begin{array}{c}\text { Positive } \\
\text { affect } \\
\text { (PANAS) }\end{array}$ & $\begin{array}{c}\text { Negative } \\
\text { affect } \\
\text { (PANAS) }\end{array}$ \\
\hline SCQ-14 & $\begin{array}{l}55.97 \pm \\
22.240\end{array}$ & $0.694^{* * *}$ & 0.060 & $0.445^{* * *}$ & $0.281^{* * *}$ & -0.021 \\
\hline STS & & $\begin{array}{l}29.25 \pm \\
6.920\end{array}$ & -0.013 & $0.371^{* * *}$ & $0.275^{* * *}$ & 0.017 \\
\hline $\begin{array}{l}\text { Rational } \\
\text { thinking style } \\
\text { (REI) }\end{array}$ & & & $\begin{array}{l}74.55 \pm \\
11.721\end{array}$ & $0.195^{* * *}$ & $0.380^{* * *}$ & $-0.123^{*}$ \\
\hline $\begin{array}{l}\text { Experiential } \\
\text { thinking style } \\
\text { (REI) }\end{array}$ & & & & $\begin{array}{l}65.80 \pm \\
11.733\end{array}$ & $0.318^{* * *}$ & -0.057 \\
\hline $\begin{array}{l}\text { Positive affect } \\
\text { (PANAS) }\end{array}$ & & & & & $\begin{array}{l}34.00 \pm \\
6.476\end{array}$ & $-0.300^{* * *}$ \\
\hline $\begin{array}{l}\text { Negative affect } \\
\text { (PANAS) }\end{array}$ & & & & & & $\begin{array}{l}20.53 \pm \\
6.882\end{array}$ \\
\hline
\end{tabular}

Note. $n=387$. SCQ-14 = Spiritual Connection Questionnaire, STS = Spiritual Transcendence Scale, REI $=$ Rational-Experiential Inventory, PANAS $=$ Positive and Negative Affect Schedule, ${ }^{*}: p<0.05,{ }^{* * *}: p<0.001$

According to the results of the hierarchical linear regression analysis, as it is presented in Table 3, positive affect significantly contributed to SCQ-14 score $(\beta=0.271, p<0.001)$ after controlling for gender, age, and educational qualification in Step 2. However, after entering experiential thinking style and spiritual transcendence in the regression (Step 3), positive affect lost its significance and both experiential thinking style $(\beta=0.208, p<0.001)$ and spiritual transcendence $(\beta=0.663, p<0.001)$ emerged as significant contributors to spiritual connection. The final equation explained $56.1 \%$ of the total variance of spiritual connection $(p<0.001)$. 
Table 3. Steps of the hierarchical linear regression analysis with spiritual connection score as criterion variable in Sample 1

\begin{tabular}{|c|c|c|c|c|c|c|}
\hline \multirow[t]{2}{*}{ Variables } & \multicolumn{2}{|c|}{$\begin{array}{c}\text { Step } 1 \\
\mathbf{F}=3.014, p=0.03 \\
\mathbf{R}^{2}=0.024\end{array}$} & \multicolumn{2}{|c|}{$\begin{array}{c}\text { Step } 2 \\
\mathbf{F}=9.689, p<0.001 \\
\mathbf{R}^{2}=0.094, \Delta \mathbf{R}^{2}= \\
0.071, p_{\text {change }}<0.001\end{array}$} & \multicolumn{2}{|c|}{$\begin{array}{c}\text { Step } 3 \\
F=79.119, p<0.001 \\
R^{2}=0.561, \Delta R^{2}= \\
0.467, p_{\text {change }}<0.001\end{array}$} \\
\hline & $\begin{array}{l}\text { standard- } \\
\text { ized } \beta\end{array}$ & $p$ & $\begin{array}{l}\text { standard- } \\
\text { ized } \beta\end{array}$ & $p$ & $\begin{array}{l}\text { standard- } \\
\text { ized } \beta\end{array}$ & $p$ \\
\hline Gender & 0.119 & 0.022 & 0.088 & 0.079 & -0.040 & 0.267 \\
\hline Age & 0.092 & 0.102 & 0.074 & 0.171 & -0.030 & 0.440 \\
\hline $\begin{array}{l}\text { Educational } \\
\text { qualification } 2\end{array}$ & 0.024 & 0.671 & -0.012 & 0.826 & -0.003 & 0.933 \\
\hline $\begin{array}{l}\text { Positive affect } \\
\text { (PANAS) }\end{array}$ & & & 0.271 & $<0.001$ & 0.066 & 0.076 \\
\hline $\begin{array}{l}\text { Experiential } \\
\text { thinking style } \\
\text { (REI) }\end{array}$ & & & & & 0.208 & $<0.001$ \\
\hline $\begin{array}{l}\text { Spiritual } \\
\text { transcendence } \\
\text { (STS) }\end{array}$ & & & & & 0.663 & $<0.001$ \\
\hline
\end{tabular}

Note. $n=387$. The following variable was excluded from the analysis as it is constant or has missing correlations: educational qualification 1. REI = Rational-Experiential Inventory; STS $=$ Spiritual Transcendence Scale, PANAS $=$ Positive and Negative Affect Schedule.

\subsection{Sample 2}

Similar to Sample 1, the Hungarian version of the SCQ-14 is characterized by excellent internal consistency (Cronbach's $\alpha=0.97$ ) in Sample 2. Again, CFA indicated inappropriate fit with the theoretically assumed one-factor model $\chi^{2}=247.132, \mathrm{df}=77, p<0.001 ; \mathrm{CFI}=0.917 ; \mathrm{NFI}=0.885 ; \mathrm{RMSEA}=0.123$ [90\% CI $=0.106-0.141]$ ), which could not be further improved by assuming associations between variables based on high modification indices. Also, EFA indicates a clear one-factor structure: the only factor with an eigenvalue higher than 1 (9.836) explains $70.25 \%$ of the total variance. Moreover, loadings of all items on factor 1 are higher than 0.65 .

Descriptive statistics of the measured variables and results of the correlation analysis are presented in Table 4. The SCQ-14 score shows a strong 
correlation with STS $\left(r_{\mathrm{s}}=0.65, p<0.001\right)$, and with the experiential thinking style $\left(r_{\mathrm{s}}=0.66, p<0.001\right)$, and no association with positive affect, negative affect, and rational thinking style.

Table 4. Descriptive statistics $(\mathrm{M} \pm \mathrm{SD})$ of the assessed variables, and results of correlation analysis (Spearman's rho coefficients) in Sample 2

\begin{tabular}{|c|c|c|c|c|c|c|}
\hline Variables & SCQ-14 & STS & $\begin{array}{c}\text { Rational } \\
\text { thinking } \\
\text { style (REI) }\end{array}$ & $\begin{array}{c}\text { Experiential } \\
\text { thinking } \\
\text { style (REI) }\end{array}$ & $\begin{array}{c}\text { Positive } \\
\text { affect } \\
\text { (PANAS) }\end{array}$ & $\begin{array}{l}\text { Negative } \\
\text { affect } \\
\text { (PANAS) }\end{array}$ \\
\hline SCQ-14 & $\begin{array}{l}63.69 \pm \\
24.516\end{array}$ & $0.654^{* * *}$ & -0.020 & $0.664^{* * *}$ & 0.133 & -0.100 \\
\hline STS & & $\begin{array}{l}28.97 \pm \\
7.845\end{array}$ & -0.046 & $0.513^{* * *}$ & 0.062 & 0.077 \\
\hline $\begin{array}{l}\text { Rational } \\
\text { thinking style } \\
\text { (REI) }\end{array}$ & & & $\begin{array}{l}77.67 \pm \\
10.945\end{array}$ & -0.019 & $0.395^{* * *}$ & $-0.206^{*}$ \\
\hline $\begin{array}{l}\text { Experiential } \\
\text { thinking style } \\
\text { (REI) }\end{array}$ & & & & $\begin{array}{l}66.32 \pm \\
12.624\end{array}$ & 0.155 & 0.014 \\
\hline $\begin{array}{l}\text { Positive affect } \\
\text { (PANAS) }\end{array}$ & & & & & $\begin{array}{l}37.03 \pm \\
5.625\end{array}$ & $-0.250^{* *}$ \\
\hline $\begin{array}{l}\text { Negative affect } \\
\text { (PANAS) }\end{array}$ & & & & & & $\begin{array}{l}18.86 \pm \\
5.715\end{array}$ \\
\hline
\end{tabular}

Note. $n=145$. SCQ-14 = Spiritual Connection Questionnaire; STS = Spiritual Transcendence Scale; REI = Rational-Experiential Inventory; PANAS $=$ Positive and Negative Affect Schedule. ${ }^{*}: p<0.05,{ }^{* *}: p<0.01,{ }^{* * *}: p<0.001$

In line with the findings obtained from Sample 1, results of the hierarchical linear regression analysis show that, after controlling for gender, age, educational qualification, and positive affect, experiential thinking style and spiritual transcendence significantly contribute to spiritual connection $(\beta=0.414, p<0.001$; and $\beta=0.495, p<0.001$, respectively). Results of the regression analysis in Sample 2 are presented in Table 5. The final equation explained $59.1 \%$ of the total variance of spiritual connection $(p<0.001)$. 
Table 5. Steps of the hierarchical linear regression analysis with spiritual connection score as criterion variable in Sample 2

\begin{tabular}{|c|c|c|c|c|c|c|}
\hline \multirow[t]{2}{*}{ Variables } & \multicolumn{2}{|c|}{$\begin{array}{c}\text { Step } 1 \\
\mathrm{~F}=1.281, p=0.283 \\
\mathrm{R}^{2}=0.027\end{array}$} & \multicolumn{2}{|c|}{$\begin{array}{c}\text { Step } 2 \\
\mathrm{~F}=1.406, p=.235 \\
\mathrm{R}^{2}=0.039, \Delta \mathrm{R}^{2}= \\
0.012, p_{\text {change }}=\mathbf{0 . 1 8 7}\end{array}$} & \multicolumn{2}{|c|}{$\begin{array}{c}\text { Step } 3 \\
\mathrm{~F}=33.060 ; p<0.001 \\
\mathrm{R}^{2}=0.591, \Delta \mathrm{R}^{2}= \\
0.553, p_{\text {change }}<0.001\end{array}$} \\
\hline & $\begin{array}{l}\text { standard- } \\
\text { ized } \beta\end{array}$ & $p$ & $\begin{array}{l}\text { standard- } \\
\text { ized } \beta\end{array}$ & $p$ & $\begin{array}{l}\text { standard- } \\
\text { ized } \beta\end{array}$ & $p$ \\
\hline Gender & 0.144 & 0.089 & 0.149 & 0.077 & -0.114 & 0.054 \\
\hline Age & -0.022 & 0.803 & -0.031 & 0.724 & -0.000 & 0.995 \\
\hline $\begin{array}{l}\text { Educational } \\
\text { qualification } 2\end{array}$ & -0.085 & 0.336 & -0.104 & 0.243 & -0.032 & 0.590 \\
\hline Positive affect & & & 0.113 & 0.187 & -0.008 & 0.885 \\
\hline $\begin{array}{l}\text { REI experiential } \\
\text { thinking style }\end{array}$ & & & & & 0.414 & $<0.001$ \\
\hline $\begin{array}{l}\text { STS (spiritual } \\
\text { transcendence) }\end{array}$ & & & & & -0.495 & $<0.001$ \\
\hline
\end{tabular}

Note. The following variable was excluded from the analysis as it is constant or has missing correlations: educational qualification 1. REI = Rational-Experiential Inventory; STS = Spiritual Transcendence Scale

\section{Discussion}

The Hungarian version of the Spiritual Connection Questionnaire (SCQ-14) shows a one-factor structure. The one-factor structure was supported by exploratory but not by confirmatory factor analysis; thus, further studies in other samples would be desirable. Spiritual connection is consistently associated with spiritual transcendence (as assessed with the STS) and experiential thinking style (as assessed with the REI), but not with positive and negative affect. No associations with the rational thinking style were found.

The strong association between spiritual connection and spiritual transcendence can be explained by the fact that both questionnaires capture spirituality at the level of experience in a religion-independent way (Piedmont, 1999; Wheeler \& Hyland, 2008). The SCQ-14 encompasses items assessing connection with others, the universe and happiness deriving from 
this spiritual perception. In the same vein, the STS subsumes three facets: connectedness (person as part of a larger reality), universality (belief in the unity of the world), and prayer fulfilment (joy deriving from the connection with god or what one's believe in). Accordingly, the two scales assess highly overlapping aspects of spirituality, namely the experience of interconnectedness and unity, and the feeling of happiness through this sense. Wheeler and Hyland (2008) also denotes that the sub-scale "universalism" of STS signifies spiritual connection. Overall, the strong association between the two scales strongly supports the construct validity of the Hungarian version of the SCQ-14. However, the question may arise, once the two questionnaires show such a considerable overlap, why an alternative (or at least very similar) measure is needed. A closer look at the items of STS shows that prayer or meditation are often mentioned; this can be confusing and difficult to rate for people without such practices. In contrast, the SCQ14 does not mention these terms, but phrases the items in a very ordinary language and captures common feelings and opinions. However, it often uses the term of "spirituality" or "spiritual", giving a free but possibly very similar interpretation of the 14 items for the responders. This fact might contribute to the high internal consistency values of the SCQ-14.

Spiritual connection shows a moderate to strong connection with experiential thinking style, but no association with rational thinking style. The experience of spiritual connection presumably manifests first at the level of emotions and feelings ("sense of harmonious interconnectedness", (Hungelmann et al., 1985)) which is in line with the rapid, effortless, nonverbal experiential system (Epstein, 1994; Wheeler \& Hyland, 2008). MacDonald (2000) also denotes that spirituality is inherently an experiential phenomenon. Although Epstein (1994) proposes that the experiential processing style has a long evolutionary history and operates in animals as well, it may work in a much more complex way in humans. Beyond the lower automatic and fast level, there might be a higher orbit where it interacts with the rational system and results in intuitive wisdom and creativity (Epstein, 1994). This is in line with Maslow's idea $(1966,1968)$, namely that the reciprocal, collaborative relationship between the experiential (primary, intuitive) and the conceptual (verbal, analytic) understanding has a great value in transcendent experiences, such as wise innocence or unitive consciousness (Cleary \& Shapiro, 1995).

As spirituality is linked to lower levels of depressive symptoms and suicide (Piedmont, 2007), we hypothesized a negative correlation between negative affect and spiritual connection. This is not supported by our findings. Pikó and colleagues (2011) suggest that if we make a distinction between spirituality as a connection to the transcendent or god ("religious 
aspect" of spiritual well-being) and as a search for meaning of life, goals and values ("existential aspect"), the aforementioned connection does not seem obvious. The religious aspect has low or no correlation to depression or anxiety, while people with high level on the existential aspect of spirituality are less prone to depression, anxiety, and substance abuse, and seem to possess better coping in case of chronic diseases (Pikó et al., 2011). SCQ-14 captures more the former one, the feeling of connectedness with no regard to meaning of life, which might explain the lack of association. A previous study (Komninos, 2009) reported no associations between spiritual experience/transcendence and negative affect, while another investigation (Powers et al., 2007) found a negative correlation between spiritual involvement in social justice (existential aspect) and negative affect. Notably, different measures of spirituality presumably result in different outcomes concerning negative affect, which is suggested to investigate in future studies. Furthermore, although spirituality and religiousness are associated with better mental health (Fetzer/NIA Working Group, 1999; Kopp et al., 2004), in special cases, when religiousness or spirituality is particularly important to the person, depressive symptoms are higher (Kopp et al., 2004). This relation can indicate the presence of one or more underlying variable(s), such as mental vulnerability, chronic stress, or chronic diseases. The lack of negative correlation between spirituality and negative affect in the present study could also be explained due to possible respondents of this particular group.

Concerning positive affect, we expected positive correlation between spiritual connection and positive affect. This assumption was supported by data in Sample 1, but not in Sample 2. Our mixed results can be explained as follows. Experiencing spiritual connection more often in daily life may contribute to higher level of positive affect. However, as mentioned before with respect to negative affect, existential aspects of spirituality may play a greater role in subjective well-being than its religious, i.e., experiential aspect. For example, Pikó and colleagues' (2011) results showed that religious aspect of spiritual well-being does not correlate with measures of well-being (depressive symptoms and satisfaction with life), however, it is associated with optimism and control, which are again in correlation with these well-being measures. Koenig (2008) signifies that the definition of spirituality is often contaminated with positive character traits or mental health variables. Thus, it shows correlation with mental health and wellbeing measures, but these associations are meaningless and tautological. Spiritual connection captures the experience of being connected without involving other health related aspects, which can explain its independence from positive affect. Results of the regression analysis in Sample 1 also 
strengthens this idea. Positive affect seems to be a significant contributor of spiritual connection in the second step, but after entering experiential thinking style and spiritual transcendence in the model (Step 3), positive affect lost its significance. We can conclude that the association of spiritual connection and positive affect derived from their shared variance with experiential thinking style. However, it can't be excluded that perceiving/ sensing deep connection with others and the universe in itself might lead to positive emotions and well-being as it was found in Klein and colleagues' (2016) work. They reported that mystical, i.e., spiritual experiences are associated with higher level of psychological well-being, generativity, and emotional stability. Thus, as previously some authors did (de Jager Meezenbroek et al., 2012; Koenig, 2008; Moberg, 2002), we suggest further and more specific exploration of this field, i.e., the relation of different spirituality measures and subjective well-being.

The regression analyses revealed that experiential thinking style and spiritual transcendence are two independent contributors to spiritual connection. As mentioned above, according to MacDonald (2000) spirituality is inherently an experiential construct, nevertheless, "a multidimensional construct that includes complex experiential, cognitive, affective, physiological, behavioral, and social components" (MacDonald, 2000, p. 158). Even if spiritual connection captures one single experiential aspect of spirituality, it appears to be more than experiential thinking. The variance shared by spiritual connection and spiritual transcendence which is independent of experiential thinking means that spirituality possesses something unique beyond intuitive-experiential information processing. It reflects humankind's highest nature, an important psychological component which is not an extension of other functions, dispositions or needs (Piedmont, 1999). Spiritual experiences, such as unitive consciousness or intuitive wisdom and creativity might be the outcome of collaborative interaction of the experiential and rational thinking processes (Cleary \& Shapiro, 1995; Epstein, 1994; Maslow, 1966, 1968, 1970).

In summary, the findings of the present study indicate appropriate psychometric characteristics of the SCQ-14, both in terms of internal consistency and validity. However, for psychometric soundness of the factor structure of the SCQ-14, further analyses are suggested in various samples. Besides, associations between spiritual connection and experiential thinking style have been revealed, and results of the regression analyses have shown that spirituality - more precisely spiritual experience - is a more comprehensive, unique phenomenon beyond experiential thinking style. Concerning well-being, we can assume that spiritual connection is not in direct relation with positive and negative affect. 
As limitations, however, we have to mention that the study included two Hungarian non-representative community samples with comparatively small sample sizes. Though validation results are promising, conclusions need to be drawn cautiously. First of all, neither spiritual and/or religious orientation of participants was assessed, nor diverse spiritual and/or religious populations were investigated. Thus, we cannot draw conclusions whether the SCQ-14 is religious-free measure even among Hungarian participants. The investigation of this specific aspect of SCQ-14 was not the aim of the present study; nevertheless, this would be an important task for future studies. Furthermore, it is important to note that the online sampling implies limitations and potential biases. For example, we have no data on incomplete participations or possible misunderstandings while filling out the form. In case of SCQ-14, as mentioned above, items might be sometimes overlapping and redundant. Thus, the further shortening of the questionnaire could be considered. Lastly, the current study includes crosssectional data thus no conclusions on causality can be drawn. For further investigation on the relationship between spirituality and its correlates longitudinal studies are needed. Furthermore, present research captures only a single aspect of spirituality, thus measuring more facets of spirituality at the same time might lead to better understanding of its nature, function, and holistic contribution of human life.

In conclusion, the Hungarian version of the Spiritual Connection Questionnaire (SCQ-14) appears to be a valid, psychometrically good measure of spirituality. Nevertheless, further psychometric analyses of the scale are proposed. Spiritual transcendence and intuitive-experiential information processing independently contribute to spiritual connection.

\section{References}

Bergin, A.E. (1997). Preface. In P. S. Richards \& A. E. Bergin (Eds.), A spiritual strategy for counseling and psychotherapy. American Psychological Association.

Bognár, J., Orosz, G., \& Büki, N. (2014). Az ésszerúség-megérzés kérdőív magyar adaptációja és az ego-rugalmassággal mutatott összefüggései. Pszichológia, 34(2), 129-147.

Browne, M.W., \& Cudeck, R. (1993). Alternative ways of assessing model fit. In K.A. Bollen, \& J.S. Long (Eds.), Testing structural equation models (pp. 136-162). Sage.

Chaiken, S. (1980). Heuristic versus systematic information processing and the use of source versus message cues in persuasion. Journal of Personality and Social Psychology, 39(5), 752-766.

Cleary, T., \& Shapiro, S.I. (1995). Abraham Maslow on experiential and conceptual understanding. International Journal of Transpersonal Studies, 14(1-2), 30-39.

de Jager Meezenbroek, E., Garssen, B., van den Berg, M., van Dierendonck, D., Visser, A., \& Schaufeli, W.B. (2012). Measuring spirituality as a universal human experience: A review of spirituality questionnaires. Journal of Religion and Health, 51(2), 336-354. 
Elkins, D.N., Hedstrom, L.J., Hughes, L.L., Leaf, J.A., \& Saunders, C. (1988). Toward a humanistic-phenomenological spirituality: Definition, description, and measurement. Journal of Humanistic Psychology, 28(4), 5-18.

Emmons, R.A. (2006). Spirituality. In M. Csíkszentmihályi \& I. S. Csikszentmihalyi (Eds.), A Life Worth Living. Contributions to positive psychology (pp. 62-81.). Oxford University Press.

Epstein, S. (1994). Integration of the cognitive and the psychodynamic unconscious. The American Psychologist, 49(8), 709-724.

Epstein, S. (2014). Cognitive-Experiential Theory. Oxford University Press.

Epstein, S., Pacini, R., Denes-Raj, V., \& Heier, H. (1996). Individual differences in intuitiveexperiential and analytical-rational thinking styles. Journal of Personality and Social Psychology, 71(2), 390-405.

Fetzer/NIA Working Group. (1999). Multidimensional Measurement of Religiousness/Spirituality for Use in Health Research. John E. Fetzer Institute.

Frankl, V. (1966). Self-transcendence as a human phenomenon. Journal of Humanistic Psychology, 6(2), 97-106.

Garcia-Romeu, A. (2010). Self-transcendence as a measurable transpersonal construct. Journal of Transpersonal Psychology, 42(1), 26-47.

Geary, B. (2003). The contribution of spirituality to well-being in sex offenders. ProQuest Information \& Learning.

Gyollai, Á., Simor, P., Köteles, F., \& Demetrovics, Z. (2011). The psychometric properties of the Hungarian version of the original and short form of Positive and Negative Affect Schedule (PANAS). Neuropsychopharmacologia Hungarica, 13(2), 73-79.

Hall, T.W., \& Edwards, K.J. (1996). The initial development and factor analysis of the Spiritual Assessment Inventory. Journal of Psychology and Theology, 24(3), 233-246.

Hays, J.C., Meador, K.G., Branch, P.S., \& George, L.K. (2001). The Spiritual History Scale in four dimensions (SHS-4): Validity and reliability. The Gerontologist, 41(2), 239-249.

Heelas, P., \& Woodhead, L. (2005). The spiritual revolution: why religion is giving way to spirituality. Archives de sciences sociales des religions, No 138(2), 145-251.

Henry, J. (2006). Strategies for achieving well-being. In M. Csíkszentmihályi \& I. S. Csikszentmihalyi (Eds.), A life worth living: Contributions to positive psychology (pp. 120138.). Oxford University Press.

Hill, P.C., \& Pargament, K.I. (2003). Advances in the conceptualization and measurement of religion and spirituality. Implications for physical and mental health research. The American Psychologist, 58(1), 64-74.

Hu, L., \& Bentler, P.M. (1999). Cutoff criteria for fit indexes in covariance structure analysis: Conventional criteria versus new alternatives. Structural Equation Modeling: A Multidisciplinary Journal, 6(1), 1-55.

Hungelmann, J., Kenkel-Rossi, E., Klassen, L., \& Stollenwerk, R.M. (1985). Spiritual wellbeing in older adults: Harmonious interconnectedness. Journal of Religion and Health, 24(2), 147-153.

IBM Corp. (2017). IBM SPSS Statistics for Windows, Version 25.0. (Version 25) [Computer software]. IMB Corp.

JASP Team. (2020). JASP (Version 0.14.2) [Computer software] (0.14.2) [Computer software]. https://jasp-stats.org/

Kass, J.D., Friedman, R., Leserman, J., Zuttermeister, P.C., \& Benson, H. (1991). Health outcomes and a new index of spiritual experience. Journal for the Scientific Study of Religion, 30(2), 203-211. 
Kelly, E.W., Jr. (1995). Spirituality and religion in counseling and psychotherapy: Diversity in theory and practice. American Counseling Association.

Klein, C., Keller, B., Silver, C.F., Hood, R.W., \& Streib, H. (2016). Positive adult development and 'spirituality': psychological well-being, generativity, and emotional stability. In Semantics and Psychology of 'Spirituality'. A Cross-cultural analysis. https:// pub.unibielefeld.de/record/2784419

Koenig, H.G. (2008). Concerns about measuring "spirituality" in research. The Journal of Nervous and Mental Disease, 196(5), 349-355.

Koenig, H.G., McCullough, M., \& Larson, D. (2001). Handbook of religion and health. Oxford University Press.

Komninos, T. (2009). Prosocial behavior as a moderator of the relationship between spirituality and subjective well-being. ETD Collection for Fordham University, 1-120.

Kopp, M., Skrabski, Á., \& Székely, A. (2004). Vallásosság és egészség az átalakuló társadalomban. Mentálhigiéné és Pszichoszomatika, 5(2), 103-125.

Köteles, F., Simor, P., Czető, M., Sárog, N., \& Szemerszky, R. (2016). Modern health worries The dark side of spirituality? Scandinavian Journal of Psychology, 57(4), 313-320.

Lindeman, M., \& Aarnio, K. (2007). Superstitious, magical, and paranormal beliefs: An integrative model. Journal of Research in Personality, 41(4), 731-744.

MacDonald, D.A. (2000). Spirituality: Description, measurement, and relation to the five factor model of personality. Journal of Personality, 68(1), 153-197.

Maslow, A.H. (1966). The psychology of science: A reconnaissance. Harper \& Row.

Maslow, A.H. (1968). Toward a psychology of being (2nd ed.). Van Nostrand Reinhold.

Maslow, A.H. (1969). The farther reaches of human nature. Journal of Transpersonal Psychology, 1(1), 1-9.

Maslow, A.H. (1970). Religions, values, and peak experiences. Viking Press.

Maton, K.I. (1989). The stress-buffering role of spiritual support: Cross-sectional and prospective investigations. Journal for the Scientific Study of Religion, 28(3), 310-323.

Moberg, D.O. (2002). Assessing and measuring spirituality: confronting dilemmas of universal and particular evaluative criteria. Journal of Adult Development, 9(1), 47-60.

Oman, D. (2013). Defining religion and spirituality. In R. F. Paloutzian \& C. L. Park (Eds.), Handbook of the psychology of religion and spirituality, 2nd ed (pp. 23-47). Guilford Press.

Pacini, R., \& Epstein, S. (1999). The relation of rational and experiential information processing styles to personality, basic beliefs, and the ratio-bias phenomenon. Journal of Personality and Social Psychology, 76(6), 972-987.

Pargament, K.I. (1999). The psychology of religion and spirituality? Yes and no. The International Journal for the Psychology of Religion, 9(1), 3-16.

Piedmont, R.L. (1999). Does spirituality represent the sixth factor of personality? Spiritual transcendence and the Five-Factor Model. Journal of Personality, 67(6), 985-1013.

Piedmont, R.L. (2004). Assessment of Spirituality and Religious Sentiments (ASPIRES). Technical Manual. Author.

Piedmont, R.L. (2005). The role of personality in understanding religious and spiritual constructs. In R.F. Paloutzian \& C.L. Park (Eds.), Handbook of the psychology of religion and spirituality (pp. 253-273). Guilford Press.

Piedmont, R.L. (2007). Spirituality as a robust empirical predictor of psychosocial outcomes: A cross-cultural analysis. In R.J. Estes (Ed.), Advancing Quality of Life in a Turbulent World (pp. 117-134).

Piedmont, R.L., \& Leach, M.M. (2002). Cross-cultural generalizability of the Spiritual Transcendence Scale in India: Spirituality as a universal aspect of human experience. American Behavioral Scientist, 45(12), 1888-1901. 
Pikó, B., Kovács, E., \& Kriston, P. (2011). Spiritualitás - Vallás - Egészség. Fiatalok mentális egészsége a spirituális jóllét mutatóinak tükrében. Mentálhigiéné és Pszichoszomatika, 12(3), 261-276.

Powers, D.V., Cramer, R.J., \& Grubka, J.M. (2007). Spirituality, life stress, and affective well-being. Journal of Psychology and Theology, 35(3), 235-243.

Saher, M., \& Lindeman, M. (2005). Alternative medicine: A psychological perspective. Personality and Individual Differences, 39(6), 1169-1178.

Shryack, J., Steger, M.F., Krueger, R.F., \& Kallie, C.S. (2010). The structure of virtue: An empirical investigation of the dimensionality of the virtues in action Inventory of Strengths. Personality and Individual Differences, 48(6), 714-719.

Simpson, J.A., \& Weiner, E.S.C. (1989). The Oxford English Dictionary. Clarendon Press; Oxford University Press.

Tomcsányi, T., Martos, T., Ittzés, A., Horváth-Szabó, K., Szabó, T., \& Nagy, J. (2011). A Spirituális Transzcendencia Skála hazai alkalmazása: Elmélet, pszichometriai jellemzők, kutatási eredmények és rövidített változat. Pszichológia, 31(2), 165-192.

Tversky, A., \& Kahneman, D. (1983). Extensional versus intuitive reasoning: The conjunction fallacy in probability judgment. Psychological Review, 90(4), 293-315.

Watson, D., Clark, L.A., \& Tellegen, A. (1988). Development and validation of brief measures of positive and negative affect: The PANAS scales. Journal of Personality and Social Psychology, 54(6), 1063-1070.

Wheeler, P., \& Hyland, M.E. (2008). The development of a scale to measure the experience of spiritual connection and the correlation between this experience and values. Spirituality and Health International, 9(4), 193-217.

Zinnbauer, B.J., Pargament, K.I., Cole, B., Rye, M.S., Butter, E.M., Belavich, T.G., Hipp, K.M., Scott, A.B., \& Kadar, J.L. (1997). Religion and spirituality: Unfuzzying the fuzzy. Journal for the Scientific Study of Religion, 36(4), 549-564.

\section{Acknowledgements}

This research was supported by the Hungarian National Scientific Research Fund (OTKA K 124132).

\section{Author contributions}

FK contributed to data collection and data processing in Sample 1, while BC was responsible for the same concerning Sample 2. FK conducted the factor analyses, and both of the authors performed the further statistical analyses. BC wrote the first draft of the manuscript. FK wrote sections of the manuscript and commented on the last version of the manuscript. Both authors contributed to the conception and design of the study.

\section{Conflict of interest}

The authors declare that they have no conflict of interest. 


\section{Appendix: The Hungarian version of the short form of SCQ-14}

\section{Spirituális Kapcsolat Kérdőív}

Az alábbiakban a spiritualitással kapcsolatos állításokat talál. Kérjük, minden egyes esetben döntse el azt, hogy mennyire ért vagy nem ért egyet az adott állítással és karikázza be a véleményével leginkább megegyező a számot. Nincsenek jó vagy rossz válaszok. Kérjük, ne hagyjon ki egyetlen állítást sem!

\begin{tabular}{|l|}
\hline Spirituális kapcsolat kérdőív (SCQ-14-H) \\
\hline 1: határozottan nem értek egyet \\
2: nem értek egyet \\
3: inkább nem értek egyet \\
4: nem tudom eldönteni \\
5: inkább egyetértek \\
6: egyetértek \\
7: határozottan egyetértek \\
\hline 1. A spiritualitás jobbá teszi az életemet. \\
\hline 2. Nem érzem, hogy spirituális kapcsolatban lennék a körülöttem levő világgal. \\
\hline 3. Időnként az az érzésem, mintha az emberekből egyfajta „belső fény” sugározna. \\
\hline 4. Soha nem volt olyan spirituális élményem, ami megváltoztatta az életemet. \\
\hline 5. Az élet egy nagyobb terv része. \\
\hline 6. Nem érzem, hogy létezne valamilyen, az embereket összekötő energia. \\
\hline 7. Érzem azt, hogy belső spirituális erőm van. \\
\hline 8. Nincs személyes kapcsolatom valamiféle nálam nagyobb erővel. \\
\hline 9. Érzem a másokkal való spirituális kapcsolatból származó belső erót. \\
\hline 10. A spiritualitás nem fontos számomra. \\
\hline 11. Érzem, hogy mindig véd egy végső hatalom, erő vagy lény. \\
\hline 12. Soha nem leszek senkivel spirituális kapcsolatban. \\
\hline 13. Boldoggá tesz, hogy kapcsolódom valami spirituálishoz. \\
\hline 14. Nem érzem azt, hogy bármiféle spirituális kapcsolatban lennék az univerzummal. \\
\hline
\end{tabular}

\section{Skálaképzési útmutató:}

A tételeket 7 fokozatú Likert-típusú skálán értékeljük.

Az 1., 3., 5., 7., 9., 11. és 13. tételek esetén az adott értéket rögzítjük, és ezeket összeadjuk.

A fordított tételeket - a 2., 4., 6., 8., 10., 12. és 14. itemeket - átfordítjuk (az ellentételes oldali Likert-skála értékére, értelemszerúen $1=7,2=6,3=5$, míg a 4-es érték megmarad), majd az átfordított értékeket hozzáadjuk az addigi pontszámhoz. 


\title{
A Spirituális Kapcsolat Kérdőív rövid változatának (SCQ-14) magyar validálása
}

\author{
CSALA BARBARA - KÖTELES FERENC
}

Elméleti háttér: A spiritualitás humánspecifikus jelenség, amelynek pozitív hatása a testi és mentális egészségre nézve bizonyított. Tudományos szempontból a spiritualitás meglehetősen összetett fogalom, számos különböző mérőeszközzel vizsgálható. A Spirituális Kapcsolat Kérdőív (Spiritual Connection Questionnaire, SCQ) vallástól függetlenül értékeli a spiritualitás szintjét, így vallásos és nem vallásos személyek körében egyaránt alkalmazható. Cél: Jelen kutatás célja Spirituális Kapcsolat Kérdőív rövid változatának (SCQ-14) magyar nyelvú validálása volt. További cél volt a spiritualitás gondolkozási stílussal és affektivitással való összefüggésének vizsgálata. Módszerek: A kutatás két nem reprezentatív mintából áll $(n=387$ és $n=145)$, amelynek résztvevői a Spirituális Kapcsolat Kérdőív rövid változatát, a Spirituális Transzcendencia Kérdőívet, az Észszerúség-Megérzés Kérdőívet, valamint a Pozitív és Negatív Affektivitás Skálát töltötték ki online formában. Eredmények: Az SCQ-14 magyar változata kiváló belső konzisztenciát (Cronbach- $\alpha=0,94$ az első, és 0,97 a második mintán) jelzett. A konfirmatív faktoranalízis nem mutatott megfeleló illeszkedést az eredeti egyfaktoros modellhez képest $\left(\chi^{2}=435,848, \mathrm{df}=77, p<0,001\right.$; CFI $=0,904 ; \mathrm{NFI}=0,886$; RMSEA $=0,110[90 \% \mathrm{CI}=0,100-$ $0,120]$ az első mintán, és $\chi^{2}=247,132, \mathrm{df}=77, p<0,001 ; \mathrm{CFI}=0,917 ; \mathrm{NFI}=0,885 ;$ RMSEA = $0,123[90 \%$ CI = 0,106-0,141] a második mintán). Ezzel szemben a feltáró faktoranalízis eredménye egyfaktoros modellt mutatott mindkét minta esetén. Az SCQ-14 továbbá pozitív irányú összefüggést mutatott a spirituális transzcendenciával, a tapasztalati gondolkodási stílussal, valamint részben a pozitív affektivitással is. A spirituális kapcsolat és negatív affektivitás, valamint a racionális gondolkodási stílus között nem jelentkezett szignifikáns korreláció. A mindkét mintán lefuttatott többszörös hierarchikus lineáris regresszió eredményei szerint a tapasztalati gondolkodás és a spirituális transzcendencia a nem, a kor, az iskolai végzettség és a pozitív affektivitás kontrollálása után is szignifikáns kapcsolatban maradt a spirituális kapcsolat pontszámmal. Következtetések: A Spirituális Kapcsolat Kérdőív rövid változatának magyar verziója valid, jó pszichometriai mutatókkal bíró mérőeszköz. A spirituális transzcendencia és a tapasztalati gondolkodás egymástól függetlenül is hozzájárulnak a spirituális kapcsolathoz.

Kulcsszavak: spiritualitás, SCQ-14, tapasztalati gondolkodási stílus, affektivitás

This is an open-access article distributed under the terms of the Creative Commons Attribution 4.0 International License (https://creativecommons.org/licenses/by/4.0/), which permits unrestricted use, distribution, and reproduction in any medium, provided the original author and source are credited, a link to the CC License is provided, and changes - if any - are indicated. (SID_1) 